\title{
Origin of Boron and Brine Evolution in Saline Springs in the Nangqen Basin, Southern Tibetan Plateau
}

\author{
Ji-long Han $(\mathbb{D}){ }^{1,2,3}$ Feng-qing Han ${ }^{(D),}{ }^{1,3}$ Syed-Asim Hussain, ${ }^{2,3}$ Wen-yu Liu, ${ }^{2}$ \\ Xiu-qing Nian, ${ }^{2}$ and Qing-fei $\mathrm{Mao}^{2}$ \\ ${ }^{1}$ Key Laboratory of Comprehensive and Highly Efficient Utilization of Salt Lake Resources, Qinghai Institute of Salt Lakes, \\ Chinese Academy of Sciences, Xining, Qinghai 810008, China \\ ${ }^{2}$ University of Chinese Academy of Sciences, Beijing 100049, China \\ ${ }^{3}$ Key Laboratory of Salt Lake Geology and Environment of Qinghai Province, Qinghai Institute of Salt Lakes, \\ Chinese Academy of Sciences, Xining, Qinghai 810008, China
}

Correspondence should be addressed to Feng-qing Han; hanfq@isl.ac.cn

Received 11 April 2017; Revised 8 August 2017; Accepted 8 November 2017; Published 21 January 2018

Academic Editor: Ferenc Molnar

Copyright (C) 2018 Ji-long Han et al. This is an open access article distributed under the Creative Commons Attribution License, which permits unrestricted use, distribution, and reproduction in any medium, provided the original work is properly cited.

The Nangqen Basin is a typical shearing-extensional basin situated in the hinterland of the Tibetan Plateau. It contains abundant saline spring resources and abnormal trace element enrichments. The hydrochemical molar ratios $(\mathrm{Na} / \mathrm{Cl}, \mathrm{B} / \mathrm{Cl}$, and $\mathrm{Br} / \mathrm{Cl}), \mathrm{H}-\mathrm{O}$ isotopes, and B isotopes of the saline spring were systematically measured to describe the evolution of brines and the origin of the boron. The sodium chloride coefficient of the water samples in this area is around 1.0 or slightly greater, which is characteristic of leached brines; the highest $\mathrm{B} / \mathrm{Cl}$ value is 4.25 (greater than that of seawater). The $\mathrm{Na} / \mathrm{Cl}, \mathrm{B} / \mathrm{Cl}$, and $\mathrm{Br} / \mathrm{Cl}$ values of the springs are clear indicators of a crustal origin. The $\delta^{18} \mathrm{O}$ values of the spring waters range from $-12.88 \%$ o to $-16.05 \%$, and the $\delta \mathrm{D}$ values range from $-100.91 \%$ o to $-132.98 \%$. Meanwhile the B content and B isotopes in the saline springs are in the ranges of 1.00 to $575.56 \mathrm{ppm}$ and $+3.55 \%$ o to $+29.59 \%$, respectively. It has been proven that the saline springs in the Nangqen Basin are a type of leached brine, suggesting that the saline springs have a terrestrial origin. The $\delta^{11} \mathrm{~B}-\mathrm{B}$ characteristics of the springs are similar to those observed in the Tibetan geothermal area, indicating that these two places have the same B source. Moreover, they have a crustal origin (marine carbonate rocks and volcanic rocks) instead of a deep mantle source.

\section{Introduction}

The Nangqen Basin is located within the area bounded by $96^{\circ}$ $00^{\prime}-97^{\circ} 00^{\prime} \mathrm{E}$ and $32^{\circ} 00^{\prime}-32^{\circ} 40^{\prime} \mathrm{N}$ and is a typical Tertiary pull-apart basin on the northeastern Qinghai-Tibetan Plateau. It was formed between the Late Eocene and Early Oligocene and the Eogene sandstone-conglomerate red beds are widely distributed within the basin. The evolutionary history in the area includes an early stage extrusion thrust foreland basin, a middle stage strike-slip pull-apart basin, and a late stage extrusion strike-slip foreland basin $[1,2]$. Previous research on the Nangqen Basin focused on the sedimentary characteristics of the basin fill [3-5], the basin's structural evolution [6], and the potassium-rich volcanic rocks [7]. However, little work has been done on the saline springs in this area.

According to our preliminary work, the terrain of the Nangqen Basin is very steep with a series of northwestsoutheast fault zones. This terrain results in exposing of many saline springs. Chemical analysis of the springs indicates that they are rich in $\mathrm{Na}^{+}, \mathrm{Ca}^{2+}, \mathrm{K}^{+}, \mathrm{Mg}^{2+}, \mathrm{Cl}^{-}$, and $\mathrm{SO}_{4}{ }^{2-}$ with trace amounts of $\mathrm{Br}^{-} \mathrm{Li}^{+}$and boron (B). The saline springs in the study area are a source of table salt, but they also produce a small amount of Glauber salt. However, the formation and material sources of these salts have not been studied. Investigation of the tracer element $B$ and its isotopes $\left(\delta^{11} \mathrm{~B}\right)$ in the saline springs can help determine the formation environment and chemical source of these saline springs. 
$\mathrm{B}$ is representative of the crustal elements [17]. It is a relatively lighter element with an atomic number of five, and it has two stable isotopes; the abundances of ${ }^{10} \mathrm{~B}$ and ${ }^{11} \mathrm{~B}$ are $19.82 \%$ and $80.18 \%$, respectively [18]. $\mathrm{B}$ and its isotopes are good tracers of the mass transfer processes in terrestrial systems [19-23].

$\mathrm{B}$ is highly soluble in aqueous environments and is highly reactive [24-26]. The large relative mass difference between the two isotopes $\left({ }^{11} \mathrm{~B}\right.$ and $\left.{ }^{10} \mathrm{~B}\right)$ and the different properties of the two dominant aqueous species of boron (i.e., $\mathrm{B}(\mathrm{OH})_{3}$ and $\mathrm{B}(\mathrm{OH})_{4}{ }^{-}$) lead to a significant isotopic fractionation of $\mathrm{B}$ $[10,27]$. Due to their soluble and incompatible character, the unique geochemical characteristics of B isotopes are widely used to assess numerous key geological processes, such as dehydration and metamorphism during slab subduction, ancient oceanic $\mathrm{pH}$ levels, the evolution of the formation of continental crust [28-33], magmatism and the formation of hydrothermal ore deposits $[25,26,34,35]$, the causes of anthropogenic contamination, wastewater recharge [36-38], the origin of salt lakes and groundwater $[27,39,40]$, sedimentary environment, and water-rock interactions [41, 42].

Some studies have focused on the B isotopic composition of brines from different salt lakes in Inner Qinghai, Xinjiang, and the Tibetan Provinces in western China. These studies reported that $B$ values vary in different regions $[27,43]$ and even vary among the salt lakes in the Qaidam Basin in Qinghai Province [44-48]. However, no studies have been conducted on saline springs of Nangqen Basin.

The purpose of this study is (1) to delineate the geochemical origins of the saline springs and (2) to use B isotopes of the saline springs as a tracer to determine their solute source and the geochemical processes that formed them.

\section{Geology and Tectonic Setting}

A continental collision between the Indian and Eurasian plates took place about 45-50 Ma ago (Middle Eocene), resulting in deformation within Tibet, and as a result, lithospheric shortening and thickening occurred [1]. This was one of the greatest geological events in the Asian continent. Subsequent subduction toward the northern Indian plate resulted in lateral resistance from the Yangtze plate, including main body of the Qinghai-Tibetan Plateau [49].

The Nangqen Basin is a typical shearing-extensional basin [1] situated in the hinterland of the Tibetan Plateau [50] and is very similar to the adjacent Dengqen and Baxoi Basins [49]. It is a lacustrine-dominated Cenozoic sedimentary basin on the eastern-central Tibetan Plateau near the headwaters of the Zha Qu/Lancangjiang River (also called the Mekong River in Thailand) with an average elevation of over $4000 \mathrm{~m}$ [50]. This NW-SE elongated basin is approximately $55 \mathrm{~km}$ long and $18 \mathrm{~km}$ wide [51] and is situated in the central part of the Qiangtang terrane [50]. To the east of the basin a thrust fault is in contact with Late Triassic limestone, while to the west Carboniferous and Permian organic limestone is unconformably overlain by Tertiary units [49]. It is an asymmetric continental sedimentary basin whose basement dips to the east, and its strata are thicker on the eastern side $[1,49]$.
This basin contains volcanic and subvolcanic rocks. The volcanic rocks of the Nangqen Basin include trachytes, latites, shoshonites, tephrites, tephriphonolites, and phonotephrites that erupted 38.7 $\mathrm{Ma}\left({ }^{40} \mathrm{Ar}-{ }^{39} \mathrm{Ar}\right.$ plagioclase age) [52]. These volcanic rocks belong to the shoshonitic series and were concluded to be formed by partial melting of an enriched mantle source $[52,53]$. All of the rocks are characterized by high $\mathrm{K}_{2} \mathrm{O}$, as is typical of the shoshonite series [54].

Early Tertiary sandstone-conglomerate red beds are widely distributed within the basin. The sandstoneconglomerate red beds are overthrust by Late Triassic limestones in the eastern part of the basin, while the limestones are unconformably overlain by these red beds in the western part of the basin [1]. These red beds exhibit an intrusive contact, although a few of them have large-scale bedding contacts. Pull-apart basins are well developed along the Lancangjiang fault due to the intracontinental deformation conditions present in this area. Only when the basement fault reaches the upper mantle, can partial melting of deep mantle material occur, which leads to volcanism. The following stages are a series of intimately related events: the closing of the Tethys, intracontinental deformation, strikeslip movement of the Lancangjiang fault, development of the terrestrial pull-apart basin, and eruption of the potassic magmas. These lithospheric evolutionary phases provide tectonic evidence for the intraplate postcollisional environments of the volcanism. Volcanism in this area is characteristic of a typical postcollisional setting and is similar to the potassic volcanism in the Alps and the Roman province. The trace elements characteristics of these volcanics are analogous to the potassic volcanic rocks in northern Tibet, which can be ascribed to the same geotectonic environment [49].

The hydrology of the area is controlled by five rivers, that is, the Zhaqu, Ziqu, Jiqu, Baqu, and Requ Rivers (Figure 1). Until now, 7 saline springs had been located and utilized. In the course of this study, we identified several more saline springs in an untraversed region that had not previously been found or utilized because of the inconvenience of reaching the area. The exposed saline springs are predominantly located in sandstone composed of volcanic rocks of the Eocene sequences. The other lithology of the area around the saline springs (from bottom to top) is interbedded mud stone, silt stone, with an intermixed layer of gypsum, and mudstone. In the study area, a series of fractures, which are very important to the formation and development of the basin, can be found to the northwest and southeast, and saline springs are exposed in the fault zones. The unbalanced development and multistage activity of these fractures are concluded to be conducive to the formation of a salt basin tectonic environment $[4,5]$.

\section{Samples and Analytical Methods}

3.1. Sample Collection. During our field investigations 7 saline spring resources were identified in the Nangqen Basin. Samples were collected from the 7 saline springs in June 2014 and November 2014. The sampling locations are listed in Table 1. Due to the negligible effects of seasonal variations 


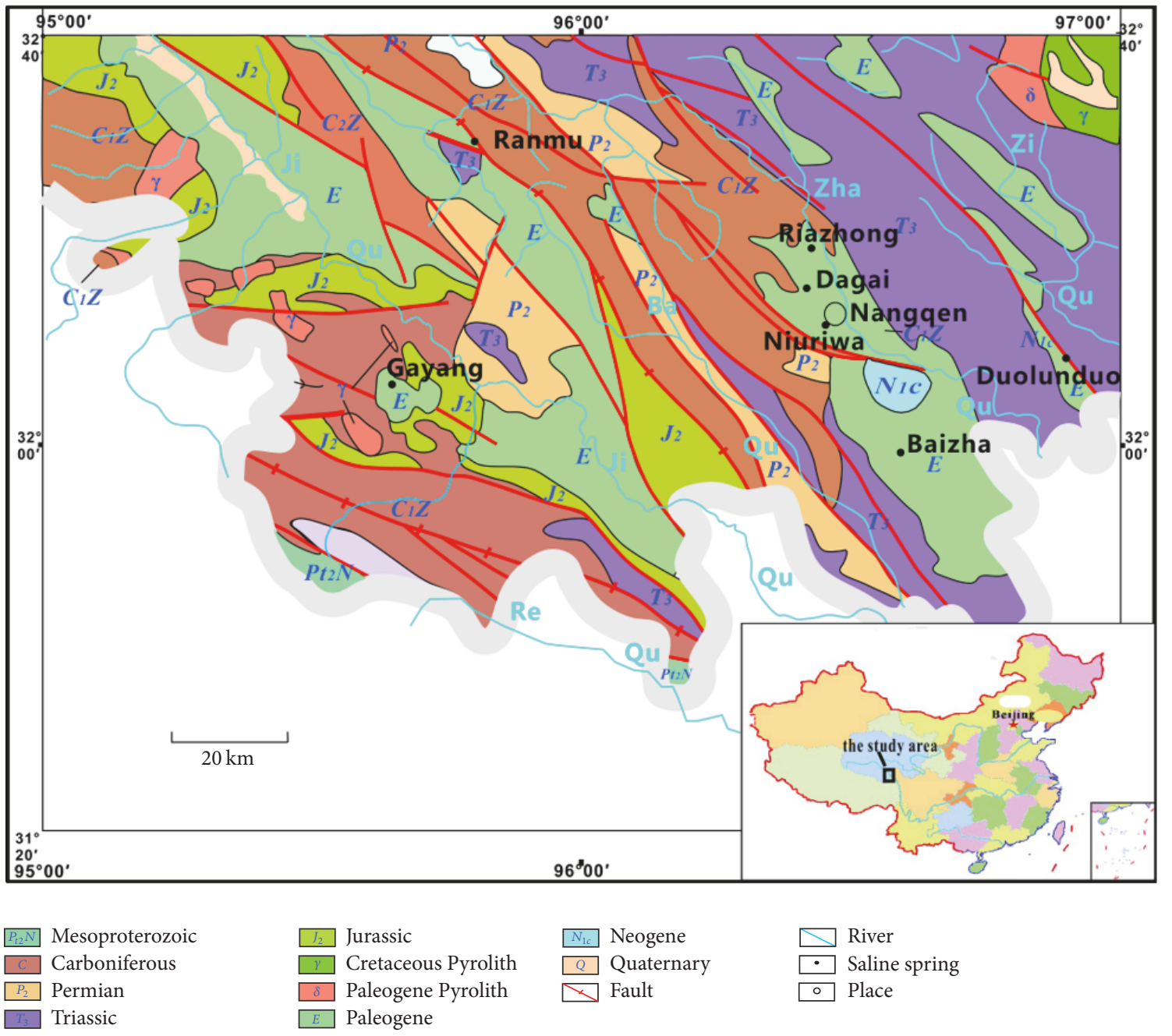

FIGURE 1: Simplified geologic map of the Nangqen Basin (modified after Han et al. [8]).

TABLE 1: Sampling sites.

\begin{tabular}{llcc}
\hline Saline spring & Location & Rock type & Age \\
\hline Dagai & $\mathrm{N} 32^{\circ} 12^{\prime} 15.1^{\prime \prime} \mathrm{E} 96^{\circ}$ & Sandstone + mudstone & Paleogene \\
Riazhong & $\mathrm{N} 32^{\circ} 15^{\prime} 58.8^{\prime \prime} \mathrm{E} 96^{\circ}$ & Sandstone, gypsum + mudstone & Paleogene \\
Niuriwa & $\mathrm{N} 32^{\circ} 08^{\prime} 38.7^{\prime \prime} \mathrm{E} 96^{\circ}$ & Sandstone, gypsum + mudstone & Paleogene \\
Duolunduo & $\mathrm{N} 32^{\circ} 04^{\prime} 48.5^{\prime \prime} \mathrm{E} 96^{\circ}$ & Sandstone, volcanic rock + mudstone & Paleogene \\
Baizha & $\mathrm{N} 31^{\circ} 56^{\prime} 02.6^{\prime \prime} \mathrm{E} 96^{\circ}$ & Sandstone + mudstone & Paleogene \\
Ranmu & $\mathrm{N} 32^{\circ} 26^{\prime} 43.1^{\prime \prime} \mathrm{E} 95^{\circ}$ & Clay & Paleogene \\
Gayang & $\mathrm{N} 32^{\circ} 03^{\prime} 47.9^{\prime \prime} \mathrm{E} 95^{\circ}$ & Sandstone + mudstone & Paleogene \\
\hline
\end{tabular}

on the runoff of the saline springs in our research area, we selected only one season for $\delta^{11} \mathrm{~B}, \delta \mathrm{D}$, and $\delta^{18} \mathrm{O}$ analysis. All water samples were filtered in situ and then stored in separate $2 \mathrm{~L}$ polyethylene bottles, which were thoroughly rinsed with deionized water before use. Unstable parameters, such as water temperature $(T), \mathrm{pH}$, and electrical conductivity (EC), were determined on site using a thermometer, a $\mathrm{pH}$ meter (SevenGo SG2, Mettler Toledo, Swiss), and a conductivity meter (SevenGo SG3, Mettler Toledo, Swiss), respectively.
3.2. Analytical Methods. All sample analyses were performed at the Salt Lake Analytical and Test Department of the Qinghai Institute of Salt Lakes, Chinese Academy of Sciences.

The concentrations of $\mathrm{Ca}^{2+}, \mathrm{Mg}^{2+}$, and $\mathrm{Cl}^{-}$were determined using chemical titration for the concentrations of $\mathrm{K}^{+}$ and $\mathrm{SO}_{4}{ }^{2-}$ were obtained using gravimetric analysis. The concentration of $\mathrm{Na}^{+}$was estimated via subtraction, and the concentrations of $\mathrm{B}_{2} \mathrm{O}_{3}$ and $\mathrm{Li}$ were analyzed by Plasma spectrometry (ICAP6500DUO, USA). Br was analyzed using 
a Uv-vis spectrophotometer (TU-1810, China). Analytical uncertainties are less than $\pm 5 \%$ for $\mathrm{B}_{2} \mathrm{O}_{3}, \mathrm{Li}$, and $\mathrm{Br}$, less than $\pm 2 \%$ for $\mathrm{Na}^{+}$, and less than $\pm 0.5 \%$ for all of the other elements analyzed.

The analytical procedure for B analysis is described in detail below.

A 2-column procedure was used for the B separation. The first column is a mixed cation-anion resin column, and the second column is an Amberlite IRA743 B-specific resin column. The mixed resin consists of a 200-400 mesh strongly acidic cation resin (Dowex $50 \mathrm{~W} \times 8 \mathrm{H}^{+}$, USA) and a 60-100 mesh weak alkaline anion resin (Ion Exchanger II, $\mathrm{HCO}_{3}{ }^{-}$, Germany). The Amberlite IRA $743 \mathrm{~B}$-specific resin was first conditioned with $\mathrm{HCl}$ solution. Then, the anion resin was leached with a saturated $\mathrm{NaHCO}_{3}$ solution. Finally, the column was washed with DI water to achieve a neutral $\mathrm{pH}$ prior to the next use (see also [55]).

$B$ purification and separation were accomplished in three steps.

The samples were passed through a special B adsorption resin column, with a velocity of $2.5 \mathrm{~mL} \mathrm{~min}^{-1}$. Then the leachate was collected and processed with a $\mathrm{B} \mathrm{HCl}$ elution $\left(500 \mu \mathrm{L}, 75^{\circ} \mathrm{C}\right.$, and $\left.0.1 \mathrm{molL}^{-1}\right)$.

Next, $0.5 \mathrm{~mL}$ of solution was concentrated and purified in a furnace at $60^{\circ} \mathrm{C}$. Then it was loaded into the mixed anion and cation exchange resin column, after which the leachate was collected and processed with an elution of $15 \mathrm{~mL}$ of low B water.

Appropriate amounts of $\mathrm{Cs}_{2} \mathrm{CO}_{3}$ and mannitol were added in order to keep the mole ratio of $\mathrm{B} / \mathrm{Cs}$ at $2: 1$ and that of $\mathrm{B} / \mathrm{mannitol}$ at $1: 1$. Then, they were concentrated to $1 \mathrm{mg} \mathrm{mL}^{-1}$ by heating at $<60^{\circ} \mathrm{C}$.

The ${ }^{11} \mathrm{~B} /{ }^{10} \mathrm{~B}$ ratio was measured on a thermal ionization mass spectrometer (Thermo Fisher Finnigan, Germany). The $\mathrm{B}$ isotopic composition can be expressed as follows:

$$
\delta^{11} \mathrm{~B}(\%)=\left[\frac{\left({ }^{11} \mathrm{~B} /{ }^{10} \mathrm{~B}\right)_{\text {sample }}}{\left({ }^{11} \mathrm{~B} /{ }^{10} \mathrm{~B}\right)_{\text {standard }}}-1\right] \times 1000 .
$$

$\left({ }^{11} \mathrm{~B} /{ }^{10} \mathrm{~B}\right)_{\text {standard }}$ NIST $951=4.05262 \pm 0.00077(2 \sigma=0.02 \%$, $n=9)$.

For $\delta \mathrm{D}$ and $\delta^{18} \mathrm{O}$ isotopes, we used MAT253 (Thermo Fisher Scientific, USA) and a Flash HT-IRMS analysis system [56].

VSMOW2 was used as the $\mathrm{H}_{2} \mathrm{O}$ standard with $\delta \mathrm{D}_{\text {VSMOW }} / \%$ o $=0 \pm 0.3$ and $\delta^{18} \mathrm{O}_{\text {VSMOW }} / \%$ o $=0 \pm 0.02$.

Standards GBW04401-GBW04404 were also used with GBW04401 having $\delta \mathrm{D}_{\mathrm{VSMOW}} / \%=-0.4 \pm 1.0$ and $\delta^{18} \mathrm{O}_{\text {VSMOW }} / \%$ o $=0.32 \pm 0.19$, GBW04402 having $\delta \mathrm{D}_{\mathrm{VSMOW}} / \%=-64.8 \pm 1.1$ and $\delta^{18} \mathrm{O}_{\text {VSMOW }} / \%=-8.79 \pm 0.14$, GBW04403 having $\delta \mathrm{D}_{\mathrm{VSMOW}} / \%=-189.1 \pm 1.1$ and $\delta^{18} \mathrm{O}_{\text {VSMOW }} / \%=-24.52 \pm 0.20$, and GBW04401 having $\delta \mathrm{D}_{\mathrm{VSMOW}} / \% \mathrm{o}=-428.3 \pm 1.2$ and $\delta^{18} \mathrm{O}_{\text {VSMOW }} / \%=-55.16 \pm 0.24$.

\section{Results}

see Tables 2 and 3.

\section{Discussion}

5.1. Geochemical Analysis. The geochemical analysis results for the samples in this study are reported in Table 2. The salinity of the saline springs in this area is $150 \mathrm{~g} / \mathrm{L}$ or greater. $\mathrm{Na}^{+}$and $\mathrm{Cl}^{-}$were found to be the main cation and anion, respectively, in our water samples. Very small concentration (changes of less than an order of magnitude) was obtained for all of the other ions analyzed, such as $\mathrm{Ca}^{2+}, \mathrm{Mg}^{2+}, \mathrm{K}^{+}$, and $\mathrm{SO}_{4}{ }^{2-}$. Trace amounts of some ions (e.g., $\mathrm{B}^{3+}, \mathrm{Li}^{+}$, and $\mathrm{Br}^{-}$) were also present in most of the saline springs.

\subsection{Genetic Analysis of Brine}

5.2.1. H-O Isotopes. In order to ascertain the source of the saline springs, hydrogen and oxygen isotopes were measured for all samples. In the same area five saline springs were identified and $\mathrm{H}$ and $\mathrm{O}$ isotopic analyses were performed by the Qinghai geophysical prospecting team in 1987 (Figure 2). The $\delta^{18} \mathrm{O}$ values in the spring waters ranged from $-12.88 \%$ to $-16.05 \%$, and the $\delta \mathrm{D}$ values ranged from $-100.91 \%$ o to $-132.98 \%$ (Table 3 ). The $\mathrm{H}-\mathrm{O}$ isotopic values of the five saline springs analyzed in 1987 were very similar to the seven saline springs analyzed in 2014. Similar values of $\mathrm{H}-\mathrm{O}$ isotopes were reported for saline springs in Canada [57]. In a thermal spring study in India, the $\delta \mathrm{D}-\delta^{18} \mathrm{O}$ plot also illustrated that all of the thermal waters fall near the LMWL [12].

The hydrogen and oxygen isotopic compositions of all seven samples were near the global water line value. According to Figure 2, the source of the saline spring waters is atmospheric precipitation and infiltration.

5.2.2. $\mathrm{Na} / \mathrm{Cl}$ and $\mathrm{B} / \mathrm{Cl}$ Ratios. $\mathrm{Na} / \mathrm{Cl}$ and $\mathrm{B} / \mathrm{Cl}$ molar ratios can be used to distinguish between the various sources of dissolved solids in salt lakes [27, 58]. Water with low $\mathrm{B} / \mathrm{Cl}$ ratios suggests a sea water source [13].

In our study, we used the relationship between these two parameters to investigate the sources of salts in the saline springs (Figure 3 ).

The $\mathrm{Na} / \mathrm{Cl}$ ratio reflects the degree of enrichment of sodium in the salt brine, which is bounded at 0.86 . The coefficient of sodium chloride in a sedimentary brine is considered to be less than 0.86 , and the coefficient of sodium chloride in a leached brine is generally high, close to 1 [59]. The coefficient of sodium chloride for the water samples in the study area is around 1.0 or slightly greater than 1.0 , indicating that they are leached brines. The $\mathrm{B} / \mathrm{Cl}$ and $\mathrm{Na} / \mathrm{Cl}$ ratios display little variability in the salt springs of the Nangqen Basin. The $\mathrm{Na} / \mathrm{Cl}$ ratios of the salt springs $(\mathrm{Na} / \mathrm{Cl}$ $=1.0)$ are greater than that of seawater $(\mathrm{Na} / \mathrm{Cl}=0.86)$ and are consistent with a halite influence. These values could also suggest the input of halite $(\mathrm{Na} / \mathrm{Cl}=1, \mathrm{~B} / \mathrm{Cl}=0)$ with little addition of $\mathrm{B}$, whereas high $\mathrm{Na} / \mathrm{Cl}$ values indicate the influence of $\mathrm{Na}_{2} \mathrm{SO}_{4}$ salts, which are abundant in some saline springs (e.g., Duolunduo, Riazhong). The majority of our 


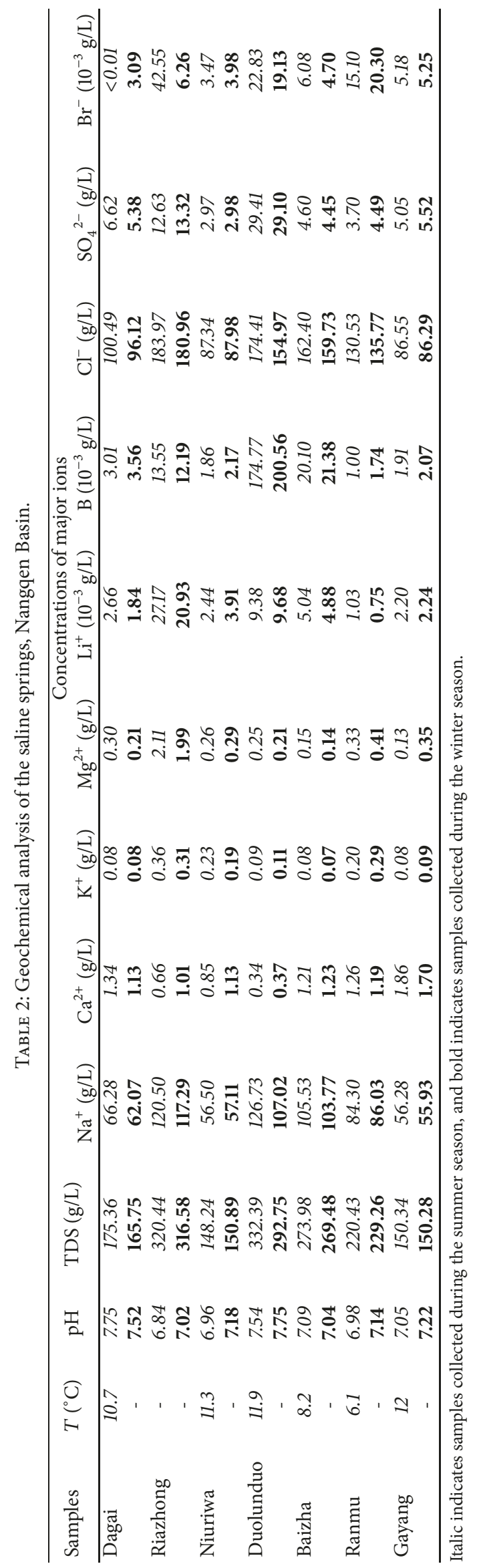


TABLE 3: B, H, and O isotopes for the saline springs, Nangqen Basin, June 2014

\begin{tabular}{lcccc}
\hline Samples & ${ }^{11} \mathrm{~B} /{ }^{10} \mathrm{~B}$ & $\delta^{11} \mathrm{~B}(\%)$ & $\delta \mathrm{D}(\%)$ & $\delta^{18} \mathrm{O}(\% \mathrm{o})$ \\
\hline Dagai & 4.07 & 4.85 & -127.39 & -14.52 \\
Riazhong & 4.10 & 12.7 & -128.28 & -14.68 \\
Niuriwa & 4.13 & 18.01 & -124.14 & -14.38 \\
Duolunduo & 4.07 & 3.55 & -100.91 & -12.88 \\
Baizha & 4.11 & 12.96 & -132.98 & -16.00 \\
Ranmu & 4.17 & 29.59 & -128.36 & -16.05 \\
Gayang & 4.13 & 18.27 & -129.57 & -15.93 \\
\hline
\end{tabular}

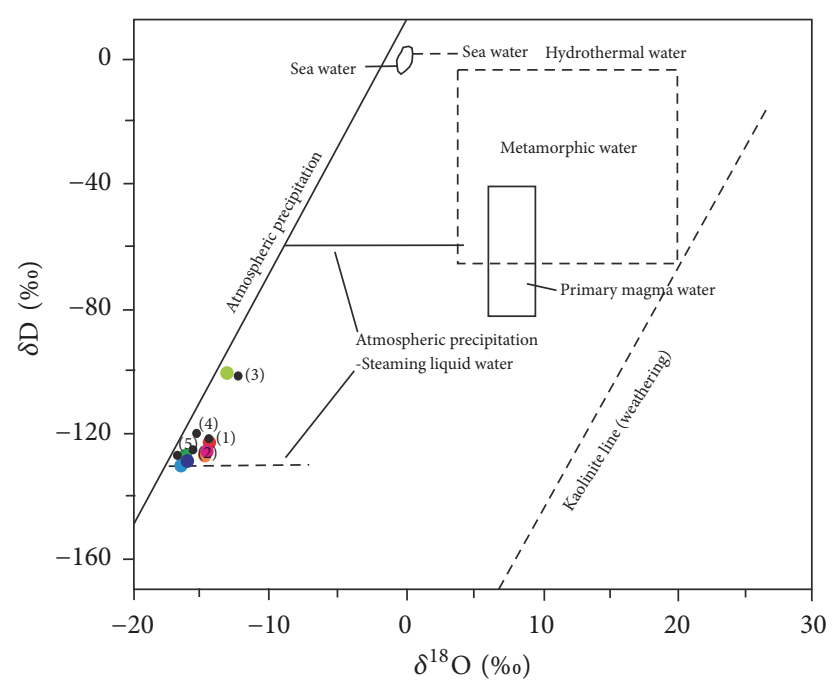
- Niuriwa
(1) Niuriwa
- Riazhong
(2) Riazhong
- Duolunduo
(3) Duolunduo
- Dagai
(4) Dagai
- Baizha
(5) Baizha
- Ranmu
- Gayang

FIgURE 2: The H-O isotopic composition of the saline springs.

samples have $\mathrm{B} / \mathrm{Cl}$ values away from the marine line $(\mathrm{Na} / \mathrm{Cl}$ $=0.86 ; \mathrm{B} / \mathrm{Cl}=7 \times 10^{-4}$ ) [27].

5.2.3. $\mathrm{Br} / \mathrm{Cl}$ Ratio. The main water reservoir (the ocean) exhibits fairly uniform $\mathrm{Cl}$ and $\mathrm{Br}$ concentrations and its $\mathrm{Cl} / \mathrm{Br}$ molar ratio is about $655 \pm 4[60,61]\left(\mathrm{Br} \times 10^{3} / \mathrm{Cl}(\mathrm{g} / \mathrm{g})\right.$ is about $3.44 \pm 0.02$ ). Thus, this ratio has been used as a tracer to determine the source and evolution of groundwater and surface water from many years $[62,63]$ and has become an important tool in studies of surface and groundwater with low-to-moderate salinity [64-67] as well as studies of the input of salinity in lakes and rivers [61, 68-70] (Figure 4).

To further distinguish the genetic type of the saline spring water, we calculated the $\mathrm{Br}$ content and the coefficient of the $\mathrm{Br} / \mathrm{Cl}$ ratio of all of the samples, as they are the most effective and sensitive index for determining the degree of concentration of the brine. All of the samples collected in our

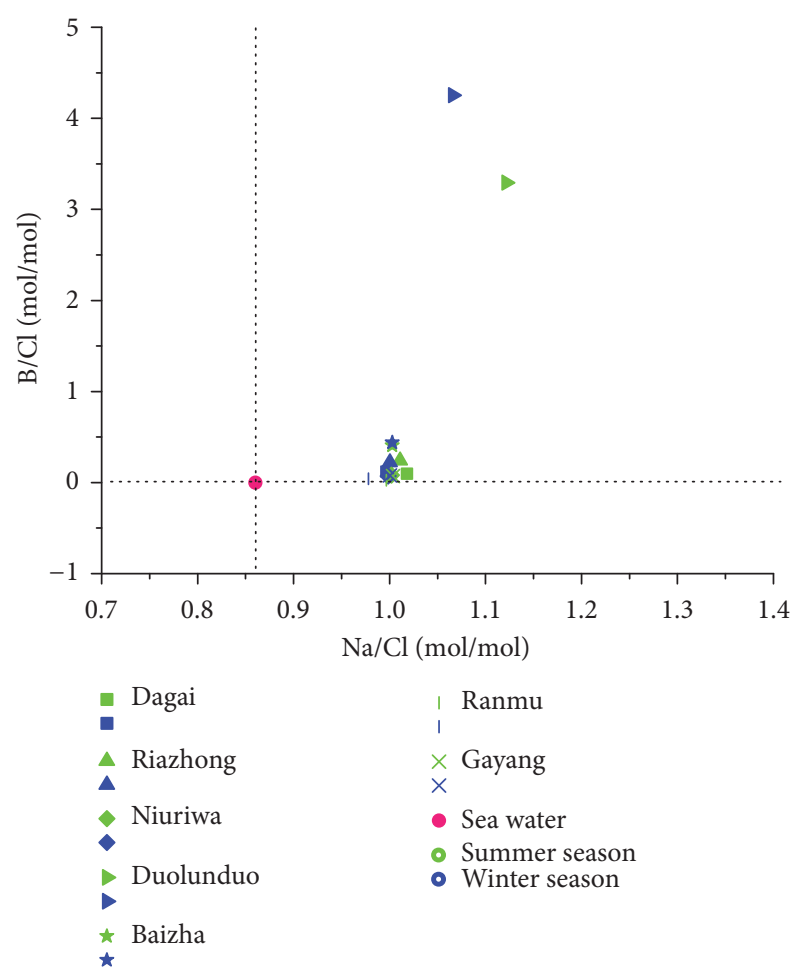

FIgURE 3: Relationship between the $\mathrm{B} / \mathrm{Cl}$ and $\mathrm{Na} / \mathrm{Cl}$ molar ratios.

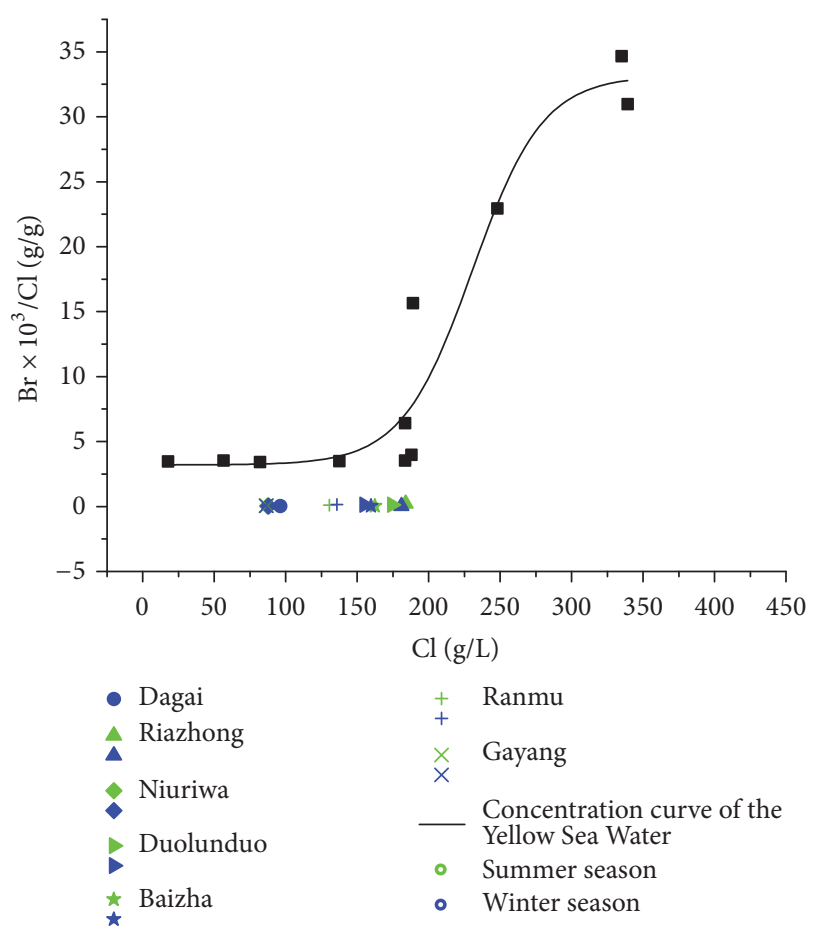

FIGURE 4: Relationship between $\mathrm{Br} \times 10^{3} / \mathrm{Cl}$ and $\mathrm{Cl}$ content. $\mathrm{Br} \times$ $10^{3} / \mathrm{Cl}$ of the black points on the concentration curve of water from the Yellow Sea are from Chen [9].

study area have low levels of bromide. Their maximum value is $42.2 \mathrm{ppm}$ (Riazhong). 
$\mathrm{Br}$ is generally nonmetallogenic by itself, so it can only be accessed based on the presence of isomorphism in the mineral crystal lattice, staying in the mother liquor [71]. $\mathrm{Br}$ in the brine is often depleted by dilution, while migration of the brine also results in adsorption, so the coefficient of $\mathrm{Br} \times 10^{3} / \mathrm{Cl}$ should be low in leached brines and high in sedimentary brines. If the coefficient of sodium chloride is $0.87-0.99$ or higher and the coefficient of $\mathrm{Br} \times 10^{3} / \mathrm{Cl}$ is $0.87-0.08$ or smaller, the saline spring is generally considered to be a leached brine [72]. The $\mathrm{Br}$ content and the coefficient of $\mathrm{Br} \times 10^{3} / \mathrm{Cl}$ indicate that these springs are leached brines.

Based on $\mathrm{Br} / \mathrm{Cl}, \mathrm{Na} / \mathrm{Cl}$, and $\mathrm{B} / \mathrm{Cl}$ ratios and the $\mathrm{H}$ $\mathrm{O}$ isotopes, it has been speculated that different kinds of saline springs were formed as a result of salt leaching when the groundwater and/or rainwater passed through salt rich stratum.

5.3. Origin of Boron. The above evidence indicates that the saline springs in the Nangqian Basin are the result of atmospheric precipitation dissolving a halite layer and that the $\mathrm{B} / \mathrm{Cl}$ ratios in the halite are as low as 0 [27]. However, the $\mathrm{B} / \mathrm{Cl}$ ratio in the saline springs in the study area is abnormal (0.03-3.29) with a maximum of 3.29 (Duolunduo). In order to understand the formation and evolution process of the saline springs and the material source of their boron, we have measured the boron isotope values. Furthermore, we will discuss the boron enriched rocks distributed in the region, which are likely to be the sources of the B in the saline springs. According to the geologic background of this area, there are carbonates and some volcanic rocks in the Nangqen Basin, with boron contents of $0.29-75.1 \mathrm{ppm}$ and $378-688 \mathrm{ppm}$ and boron isotopic values of $-5.5-20 \%$ and -16.3 to $-10.3 \%$, respectively [11].

5.3.1. The Influence of $p H$ on B Isotopes. Several studies have shown that the boron isotopic composition is controlled by $\mathrm{pH}[10,58,73,74]$. According to Palmer et al. [75], pH can restrict the boron isotopic characteristics of a water body to a certain extent. Especially in the case of low concentrations of $\mathrm{B}$, there is a linear relationship between $\mathrm{pH}$ and $\delta^{11} \mathrm{~B}$. When the $\mathrm{pH}$ of a water sample increases, there is a linear decrease in the B isotopic value. Some experiments (a hydrothermal system in Taiwan) have shown that $B$ isotopes are dependent on $\mathrm{pH}$. The $\mathrm{pH}$ values, $\mathrm{B}$ concentrations, and $\mathrm{B}$ isotopic compositions show significant correlations with each other, suggesting that the $\delta^{11} \mathrm{~B} / \mathrm{B}$ and $\mathrm{pH} / \mathrm{B}$ ratios of hydrothermal systems have stable values [14]. In our study, the effect of $\mathrm{pH}$ on the change in the $\delta^{11} \mathrm{~B}$ value is investigated, as shown in Figure 5.

$\delta^{11} \mathrm{~B}$ is stable at around $+15 \%$ when the salt spring's $\mathrm{pH}$ is approximately neutral ( $\mathrm{pH}$ of $6.8-7.2)$. However, ${ }^{11} \mathrm{~B}$ in the saline springs decreased significantly $(\geq+5 \%)$ with increasing $\mathrm{pH}$, whereas the $\mathrm{B}$ isotopic value $(+29.59 \%$ ) in the Ranmu sample indicates that it had a different source, so the influence of the $\mathrm{pH}$ value can be ignored. The linear relationship between $\delta^{11} \mathrm{~B}$ and the $\mathrm{pH}$ of the water samples is shown in Figure 5. The linear regression equation is $y$ $=-19.01 x+150.60$ with a low standard deviation value of 0.42 . The correlation is very low. Overall, there is no obvious

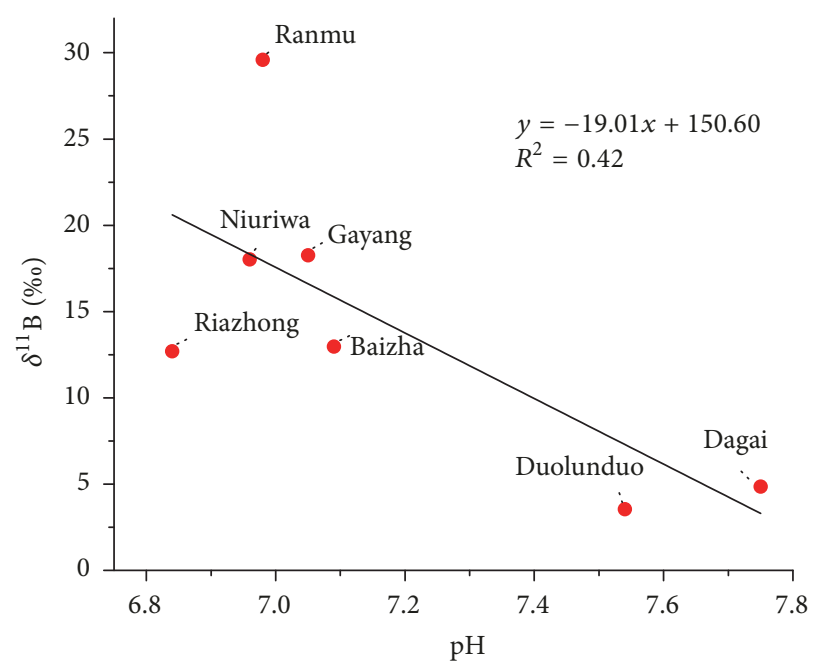

FIGURE 5: Relationship between $\delta^{11} \mathrm{~B}$ and $\mathrm{pH}$.

linear relationship between the $\mathrm{B}$ isotope and the $\mathrm{pH}$ value. Musashi et al., 1988 (Japan), also concluded that the B isotopic variation was independent of $\mathrm{pH}$ and showed a systematic regional variation [15], which can be seen in our study also.

Based on the relationship between $\delta^{11} \mathrm{~B}$ and $\mathrm{pH}$ (Figure 5), we suggest that the sample's $\mathrm{pH}$ is not the main factor influencing the variation in the $\delta^{11} \mathrm{~B}$ values in the study area. Instead, the $\delta^{11} \mathrm{~B}$ characteristics of the salt springs mainly depend on their source area. Thus, we can determine the source of the material based on the $\delta^{11} \mathrm{~B}$ characteristics.

5.3.2. The Relationship between $\delta^{11} B$ and the $B$ Content. The average $\delta^{11} \mathrm{~B}$ value of atmospheric precipitation on the Qinghai-Tibetan Plateau has not been reported. Lü et al. [11] speculated that the $\delta^{11} \mathrm{~B}$ value of atmospheric precipitation is between $-6.0 \%$ and $6.8 \%$ on the Qinghai-Tibetan Plateau based on the location of $\delta \mathrm{D}-\mathrm{Cl}$ in relation to the atmospheric precipitation line of $\mathrm{B}\left(\delta \mathrm{D}=2.6 \times \delta^{11} \mathrm{~B}-133\right)$. Our $\delta^{11} \mathrm{~B}$ results are similar to those of a rainwater sample $(5.4 \pm$ $1.4 \%$ ) in Nepal collected by Rose et al. (2000) [76]. Therefore, we assume that the Nepal rainwater and rainwater in the Nangqen Basin share the same B isotopic characteristics. As shown in Figure 6, marine carbonates $(B=3.72-24.0$ ppm) and Tertiary volcanic rocks $(\mathrm{B}=378-688 \mathrm{ppm})$ are widely distributed in this area. Therefore, we speculate that they are most likely to be the $\mathrm{B}$ source of the saline springs.

The $\delta^{11} \mathrm{~B}-\mathrm{B}$ relationships (Figure 6) indicate that the saline springs of the Nangqen Basin have the largest variations in $\delta^{11} \mathrm{~B}$ contents and boron concentrations of any saline springs, which could be related to differences in the geological and geochemical setting of the Nangqen Basin.

High $\delta^{11} \mathrm{~B}$ values indicate a deviation in $\mathrm{B}$ values from that of seawater $[17,76]$, that is, $\delta^{11} \mathrm{~B}=36.36-45.74\left({ }^{11} \mathrm{~B} /{ }^{10} \mathrm{~B}\right.$ ratio $=4.200-4.238)[77,78]$, whereas lower $\delta^{11} \mathrm{~B}$ values support a continental origin of $\mathrm{B}[17,77] . \delta^{11} \mathrm{~B}$ of the saline springs is $3.55 \%$ o to $29.59 \%$, which is significantly lower than that of seawater. Part of the Qinghai-Tibetan Plateau has 


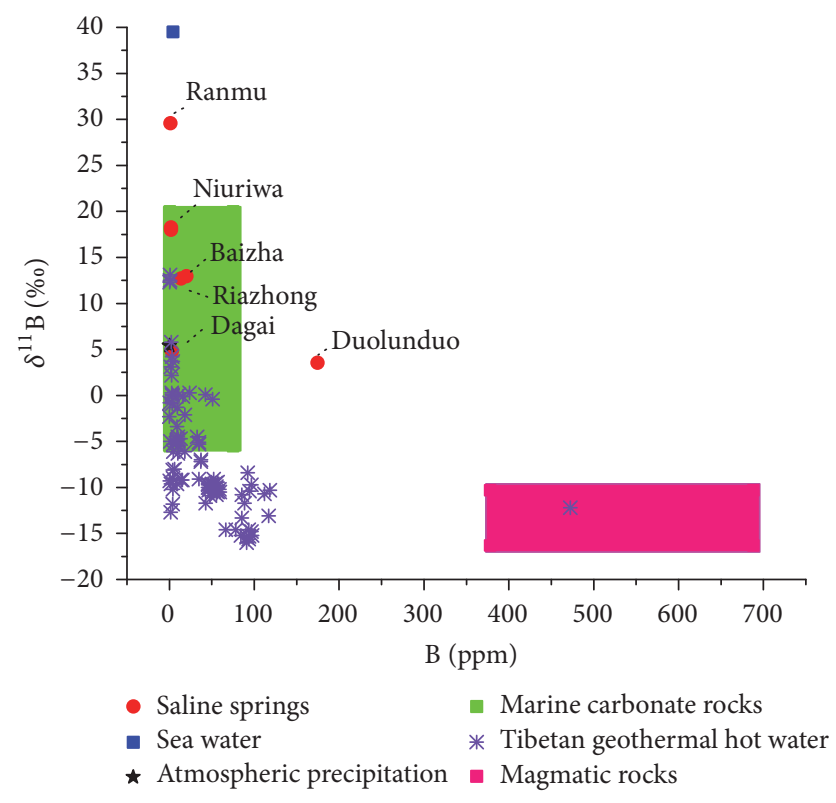

Figure 6: Relationship between $\delta^{11} \mathrm{~B}$ and $\mathrm{B}$ concentration in the saline springs of the Nangqen Basin. The green and pink shaded areas are the regions with boron geochemical characteristics of crustal marine carbonate rocks and magmatic rocks, respectively [10]. Data for Tibetan geothermal hot water is from [11].

been uplifted since the Cretaceous-Tertiary (especially in the Miocene) as discussed by Yin et al. [79, 80]. This evidence confirms that the late transgression did not penetrate into the internal part of the plateau. In summary, we conclude that B in the saline springs in the study area has a terrestrial source.

Previous studies have shown that the $\mathrm{B}$ content of the mantle is only $0.18-1.35$ ppm [81, 82]. Consequently, according to the $\mathrm{B}$ content of the saline springs in the Nangqen Basin (1.00-200.56 ppm), we speculate that mantle processes cannot provide abundant $\mathrm{B}$ and that $\mathrm{B}$-enriched water is always associated with B-enriched crustal rocks.

In some modern (shallow) marine carbonates boron isotope is recorded approximately as $30 \%$ o $[10,83]$, and the B content of marine carbonate $(0.29-75.1 \mathrm{ppm})$ in the Tibetan area is consistent with that of other marine carbonates (3.72-24.0 ppm) [11] and having similar chemical composition as reflected in our study. B in hot springs in the Tibet area (Xiqinqucan, $\delta^{11} \mathrm{~B}=12.3 \%$ to $12.5 \%$; Kangbuqucan, $\delta^{11} \mathrm{~B}=$ $13.1 \%$ ) comes mainly from marine carbonates [11]. The boron sources, enriched in the saline springs of Dagai, Riazhong, Niuriwa, Baizha, and Gayang $\left(\mathrm{B}=5.98-64.76 \mathrm{ppm}, \delta^{11} \mathrm{~B}=\right.$ $4.85 \%$ o- $18.27 \%$, green area in Figure 6 ), appear to be mainly from a marine carbonate source based on the fact that they share similar B characteristics with marine carbonate. B of the rain data is very close to that of the saline springs. The range of $B$ isotopic values for precipitation on the southern QinghaiTibet Plateau is about $-6.0 \% 0-6.8 \%$ ond the $\mathrm{B}$ content is $0.014 \mathrm{ppm}$ [11]. Thus, precipitation has little influence on the $\mathrm{B}$ isotope values of the saline springs.

The Duolunduo saline spring has a low $\delta^{11} \mathrm{~B}$ value and a high B content. Zheng et al. [84] studied the B contents of various types of rocks on the Qinghai-Tibet Plateau and established that the Precambrian metamorphic rocks, Cretaceous volcanic rocks, Cenozoic rhyolites, granites, and so on are all rich in $\mathrm{B}$, especially the Cretaceous-Paleogene volcanic rocks (378-688 ppm). Based on the large amount of volcanic rock in the Nangqen Basin and their similar isotopic values (3.55\%o) and high B contents (174.77 ppm), we hypothesize that these $B$ isotopic characteristics are the result of the combined influence of the volcanic rocks and the marine carbonates and that both rock types are the B source of the saline springs.

As compared with hot springs in Tibet, $\delta^{11} \mathrm{~B}$ of the saline springs in the Nangqen Basin is consistently higher, even for the Ranmu saline spring (high $\delta^{11} \mathrm{~B}$ value versus low $\mathrm{B}$ content). In contrast to Ranmu, the other springs (Riazhong, Niuriwa, Baizha, and Dagai) lie solely in the area of the marine carbonates (green area in Figure 6). This may be due to the fact that $\mathrm{B}$ isotopes can be adsorbed by a clay layer. In the water-rock reaction process, clay minerals can adsorb boron, and ${ }^{10} \mathrm{~B}$ preferentially goes into the solid phase [45], which results in high boron isotopic values in the saline springs. For all of the samples collected in the study area, plots of the $\delta^{11} \mathrm{~B}$ values versus the boron concentrations indicate that the saline springs in the Nangqen region have different boron sources. Moreover, the B characteristics of the two component end members were similar to those present in the Tibetan geothermal area. One end member has relatively low boron concentrations and low $\delta^{11} \mathrm{~B}$, and the other end member exhibits relatively high boron concentrations and high $\delta^{11} \mathrm{~B}$. There is a strong correlation between the strata and the fractures around the saline springs. Further investigation into the origin and evolution of boron in the saline springs in the Nangqen area is required to gain a deeper understanding of the geochemical processes that affect boron and its isotopes.

5.3.3. Comparison with Other Springs Worldwide. Terrestrial sources have low boron isotopic values, while higher boron isotopic values are characteristics of a marine source. Presentday seawater has a constant $\delta^{11} \mathrm{~B}$ value of $+39.5 \%$ and a boron concentration of approximately $4.5 \mathrm{ppm}$ [45]. The continental crust has relatively low $\delta^{11} \mathrm{~B}$ values of $-20 \%$ o-7\%o [85]. Many studies of springs worldwide show that B concentrations and $\delta^{11} \mathrm{~B}$ values can be used to determine the source of the material. We have compared our data to that of the hot springs and saline springs in Indonesia, Japan, India, Greece, and the yellow and white springs in Taiwan.

As shown in Figure 7, some springs around the world have similar $\delta^{11} \mathrm{~B}-\mathrm{B}$ relationships to that seen in our study area, while some are very different. There are many factors affecting the $\delta^{11} \mathrm{~B}$ values and B contents of these springs, such as the geological setting, wall rock compositions, and tectonic structures. Indonesia, Japan, and Greece have values similar to those of our study area; however their sources are different. The $\delta^{11} \mathrm{~B}$ values of hot springs in Indonesia range from $-2.4 \%$ o to $+28.7 \%$ ond the $\mathrm{B}$ concentrations range from 2.08 to $93.23 \mathrm{ppm}$. In the case of geothermal brines, the $\delta^{11} \mathrm{~B}$ values 


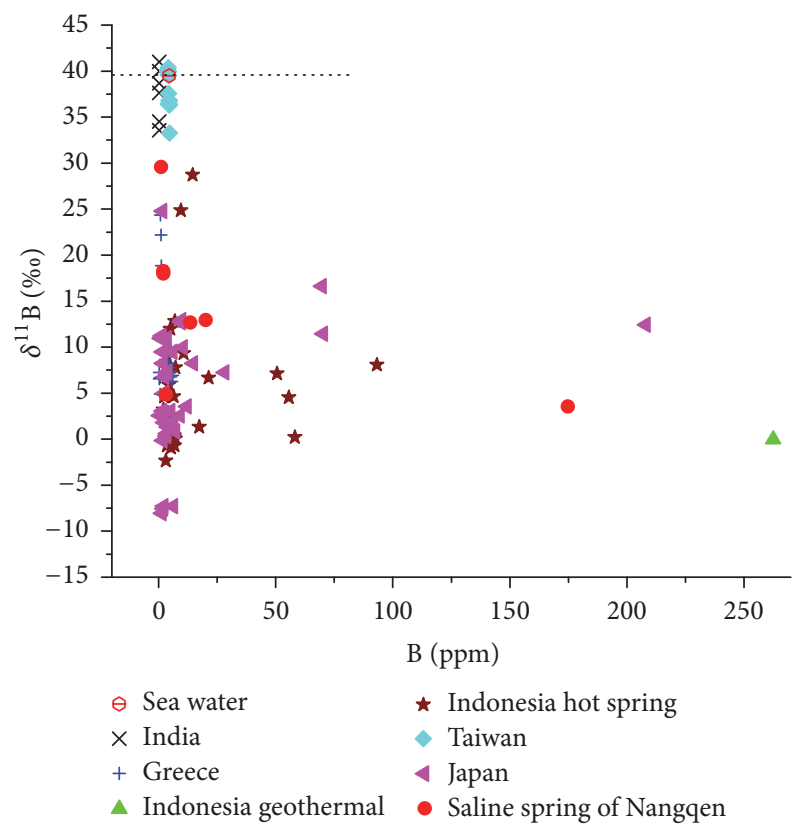

Figure 7: Comparison of springs worldwide. Data from India [12], Indonesia [13], Taiwan [14], Japan [15], and Greece [16].

range from $-0.02 \% 0$ to $0.26 \%$ and the $\mathrm{B}$ concentrations range from 262.54 to $593.6 \mathrm{ppm}$, which indicates the leaching of andesitic rocks, which is a similar conclusion to that reached regarding our saline springs (Duolunduo) [13]. In a study from (central) Japan, it was revealed that the $\delta^{11} \mathrm{~B}$ values of the springs in that area range from $-7.56 \%$ to $24.77 \%$, and the $\mathrm{B}$ contents range from 0.366 to $208 \mathrm{ppm}$. The Japanese $\mathrm{B}$ isotopic study is independent of the $\mathrm{pH}$ value and reported a systematic regional variation, which can also be seen in our study. However, in Japan the source from which the aqueous $B$ is derived and that of some springs are strongly influenced by sea water [15]. Although the data is similar to that of the Nangqen Basin springs, the source of B is entirely different because of the geological background of the areas and the influence of the surrounding rocks. In a hydrothermal system in Greece, the $\delta^{11} \mathrm{~B}$ values range from 4.90 to $24.36 \%$ with low $\mathrm{B}$ content $0.25-6.02 \mathrm{ppm}$, and it is concluded that the $\mathrm{B}$ source is sediment or magmatic influence in the deep reaction zone of the Milos hydrothermal system, which differs from the B source of the salt springs in the Nangqen Basin [16].

Hot springs in India and Taiwan have shown different $\mathrm{B}$ and $\delta^{11} \mathrm{~B}$ values than those in our study area. $\delta^{11} \mathrm{~B}$ compositions range from $+34 \%$ to $+41 \%$ in springs in India, but in our study area the B values are lower (Table 3 ). Thus, we can easily differentiate the two difference sources; that is, one is terrestrial and the other (Indian) is marine [13]. A study of the yellow spring and white spring hydrothermal fluids in Taiwan confirmed that B of the hydrothermal fluids and plumes is higher and is derived from seawater and that only a small amount of it comes from andesite. The $\mathrm{B}$ concentrations and B isotopic compositions show significant correlation, which is absent in our study area [14].

\section{Conclusions}

The saline springs in the Nangqen Basin are leached brines according to analyses of hydrogen and oxygen isotopes, $\mathrm{Na} / \mathrm{Cl}$ and $\mathrm{B} / \mathrm{Cl}$ molar ratios, and the coefficient of $\mathrm{Br} \times$ $10^{3} / \mathrm{Cl}$.

The B concentrations $(3.23-147.77 \mathrm{ppm})$ and $\delta^{11} \mathrm{~B}$ $(3.55 \% 0-29.59 \%)$ of the saline springs in the Nangqen area vary significantly. However, the variations in the $\mathrm{B} / \mathrm{Cl}$ molar ratios (0.03-3.29) are relatively small. In the Tibetan geothermal area, the B concentration is $0.036-472.4 \mathrm{ppm}$, and $\delta^{11} \mathrm{~B}$ ranges from $-16.0 \%$ to $13.1 \%$ [11]. Both values are similar to those of the Nangqen Basin. These characteristics are in sharp contrast to the geochemical characteristics of seawater and typical geothermal waters of marine origin. Therefore, it is concluded that the saline springs in the Nangqen Basin have a terrestrial source.

The $\delta^{11} \mathrm{~B}-\mathrm{B}$ binary mixing relationship in the study area indicates that marine carbonate rocks and volcanic rocks are the main sources of the $B$ in the saline springs. Therefore, we conclude that B in the saline springs has a primarily crustal source (marine carbonate rocks and volcanic rocks), instead of a deep mantle source.

Based on our study, the Nangqen area has the lowest $\delta^{11} \mathrm{~B}$ values and the largest variation in $\mathrm{B}$ concentrations. These characteristics are most likely related to the unique tectonic history of the Nangqen Basin.

\section{Conflicts of Interest}

The authors declare that they have no conflicts of interest.

\section{Acknowledgments}

The authors thank Ma Yunqi, associate research fellow, for providing valuable suggestions and help during lab experiments. They thank Zhang Xiying and Zeng Fangming for their help with revision and acknowledge LetPub (http://www.letpub.com) for the linguistic assistance during the preparation of this manuscript. This research was supported by Science and Technology Project of Qinghai Province (Grant no. 2014-ZJ-702).

\section{References}

[1] W. M. Deng, H. J. Sun, and Y. Q. Zhang, "K-Ar age of the Cenozoic volcanic rocks in the Nangqen basin, Qinghai province and its geological significance," Chinese Science Bulletin, vol. 45, no. 11, pp. 1015-1019, 2000.

[2] J. Y. Zhou, J. H. Wang, A. Yin, B. K. Horton, and M. Spurlin, "Sedimentology and tectonie significance of Paleogene coarse clastic roeks in eastern Tibet," Acta Geologicasinca, vol. 77, no. 2, pp. 262-272, 2003 (Chinese).

[3] J. Y. Zhou, J. H. Wang, A. Yin, M. S. Spurlin, and B. K. Horton, "Depositional patterns and tectonic setting of early Tertiary basins in the NE margin of the Tibetan Plateau: a case study of the Nangqian and Xialaxiu basins," Acta Sedimentologica Sinica, vol. 20, no. 1, pp. 85-91, 2002 (Chinese).

[4] B. K. Horton, J. Y. Zhou, M. S. Spurlin, and J. H. Wang, "Paleogene deposystems and basin evolution in the eastern 
Tibetan Plateau: Nangqian and Xialaxiu basins," Earth Science Frontiers (English Edition), vol. 7, supplement 1, pp. 282-283, 2000.

[5] H. F. Du, Y. B. Jiang, Z. B. Yan et al., "Sedimentary characteristics and environment of the Paleogene Nangqian Basin in Qinghai Province," Acta Gelogica Sinica, vol. 85, no. 3, pp. 383-395, 2011 (Chinese).

[6] M. S. Spurlin, A. Yin, B. K. Horton, J. Zhou, and J. Wang, "Structural evolution of the Yushu-Nangqian region and its relationship to syncollisional igneous activity, east-central Tibet," GSA Bulletin, vol. 117, no. 9-10, pp. 1293-1317, 2005.

[7] L. Zhu, H. H. Zhang, J. H. Wang, J. Y. Zhou, and G. H. Xie, “ ${ }^{40} \mathrm{Ar} /{ }^{39} \mathrm{Ar}$ Chronology of high-K magmatic rocks in Nangqian Basins at the northern segment of the Jinsha-Red river shear zone," Geotectonica et Metallogenia, vol. 30, no. 2, pp. 241-247, 2006 (Chinese).

[8] F.-Q. Han, Y.-J. Chen, J.-L. Han et al., "Boron isotope geochemical characteristics and its geological significances of high salinity salt springs in Nangqian Basin, Qinghai Province, China," Acta Geoscientia Sinica, vol. 37, no. 6, pp. 723-732, 2016 (Chinese).

[9] Y. H. Chen, "Sequence of salt separation and regularity of some trace elements distribution during isothermal evaporation $\left(25^{\circ} \mathrm{C}\right)$ of the Huanghai Sea Water," Acta Geologicia Sinica, vol. 4, pp. 379-390, 1983 (Chinese).

[10] N. G. Hemming and G. N. Hanson, "Boron isotopic composition and concentration in modern marine carbonates," Geochimica et Cosmochimica Acta, vol. 56, no. 1, pp. 537-543, 1992.

[11] Y. Y. Lü, M. P. Zheng, P. Zhao, and R. H. Xu, "Geochemical processes and origin of boron isotopes in geothermal water in the Yunnan-Tibet geothermal zone," Science China Earth Sciences, vol. 57, no. 12, pp. 2934-2944, 2014.

[12] S. Chatterjee, M. A. Ansari, A. S. Deodhar, U. K. Sinha, and A. Dash, "A multi-isotope approach $(\mathrm{O}, \mathrm{H}, \mathrm{C}, \mathrm{S}, \mathrm{B}$ and $\mathrm{Sr})$ to understand the source of water and solutes in some the thermal springs from West Coast geothermal area, India," Arabian Journal of Geosciences, vol. 10, no. 11, article 242, pp. 1-11, 2017.

[13] B. J. Purnomo, T. Pichler, and C.-F. You, "Boron isotope variations in geothermal systems on Java, Indonesia," Journal of Volcanology and Geothermal Research, vol. 311, pp. 1-8, 2016.

[14] Z. G. Zeng, X. Y. Wang, C.-T. A. Chen et al., "Boron isotope compositions of fluids and plumes from the Kueishantao hydrothermal field off northeastern Taiwan: implications for fluid origin and hydrothermal processes," Marine Chemistry, vol. 157, pp. 59-66, 2013.

[15] M. Musashi, M. Nomura, M. Okamoto, T. Ossaka, T. Oi, and H. Kakihana, "Regional variation in the boron isotopic composition of hot spring waters from central Japan.", Geochemical Journal, vol. 22, no. 5, pp. 205-214, 1988.

[16] S.-F. Wu, C.-F. You, Y.-P. Lin, E. Valsami-Jones, and E. Baltatzis, "New boron isotopic evidence for sedimentary and magmatic fluid influence in the shallow hydrothermal vent system of Milos Island (Aegean Sea, Greece)," Journal of Volcanology and Geothermal Research, vol. 310, pp. 58-71, 2016.

[17] H. R. Marschall and S.-Y. Jiang, "Tourmaline isotopes: no element left behind," Elements, vol. 7, no. 5, pp. 313-319, 2011.

[18] J. Xiao, Y. K. Xiao, Z. D. Jin, M. Y. He, and C. Q. Liu, "Boron isotope variations and its geochemical application in nature," Australian Journal of Earth Sciences, vol. 60, no. 4, pp. 431-447, 2013.
[19] J. Casanova, P. Négrel, and R. Blomqvist, "Boron isotope fractionation in groundwaters as an indicator of past permafrost conditions in the fractured crystalline bedrock of the fennoscandian shield," Water Research, vol. 39, no. 2-3, pp. 362370, 2005.

[20] B. Chetelat, J. Gaillardet, R. Freydier, and P. Négrel, "Boron isotopes in precipitation: experimental constraints and field evidence from French Guiana," Earth and Planetary Science Letters, vol. 235, no. 1-2, pp. 16-30, 2005.

[21] S. A. Kasemann, D. N. Schmidt, J. Bijma, and G. L. Foster, "In situ boron isotope analysis in marine carbonates and its application for foraminifera and palaeo-pH," Chemical Geology, vol. 260, no. 1-2, pp. 138-147, 2009.

[22] E. Anagnostou, K.-F. Huang, C.-F. You, E. L. Sikes, and R. M. Sherrell, "Evaluation of boron isotope ratio as a $\mathrm{pH}$ proxy in the deep sea coral Desmophyllum dianthus: Evidence of physiological $\mathrm{pH}$ adjustment," Earth and Planetary Science Letters, vol. 349-350, pp. 251-260, 2012.

[23] Q. S. Fan, Y. Q. Ma, H. D. Cheng et al., "Boron occurrence in halite and boron isotope geochemistry of halite in the Qarhan Salt Lake, western China," Sedimentary Geology, vol. 322, pp. 34-42, 2015.

[24] J. Xiao, Y. Xiao, Z. Jin, C. Liu, and M. He, "Boron isotopic compositions in growing corals from the South China Sea," Journal of Asian Earth Sciences, vol. 62, pp. 561-567, 2013.

[25] S.-Y. Jiang, "Boron isotope geochemistry of hydrothermal ore deposits in China: A preliminary study," Physics and Chemistry of the Earth, Part A: Solid Earth and Geodesy, vol. 26, no. 9-10, pp. 851-858, 2001.

[26] W. Zhang, H. Tan, Y. Zhang, H. Wei, and T. Dong, "Boron geochemistry from some typical Tibetan hydrothermal systems: Origin and isotopic fractionation," Applied Geochemistry, vol. 63, pp. 436-445, 2015.

[27] H.-Z. Wei, S.-Y. Jiang, H.-B. Tan, W.-J. Zhang, B.-K. Li, and T.-L. Yang, "Boron isotope geochemistry of salt sediments from the dongtai salt lake in qaidam basin: Boron budget and sources," Chemical Geology, vol. 380, pp. 74-83, 2014.

[28] M. Chaussidon and B. Marty, "Primitive boron isotope composition of the mantle," Science, vol. 269, no. 5222, pp. 383-386, 1995.

[29] S. Barth, "Application of boron isotopes for tracing sources of anthropogenic contamination in groundwater," Water Research, vol. 32, no. 3, pp. 685-690, 1998.

[30] M. Rosner, J. Erzinger, G. Franz, and R. B. Trumbull, "Slabderived boron isotope signatures in arc volcanic rocks from the Central Andes and evidence for boron isotope fractionation during progressive slab dehydration," Geochemistry, Geophysics, Geosystems, vol. 4, no. 8, pp. 1-25, 2003.

[31] M. Pagani, D. Lemarchand, A. Spivack, and J. Gaillardet, "A critical evaluation of the boron isotope-pH proxy: The accuracy of ancient ocean pH estimates," Geochimica et Cosmochimica Acta, vol. 69, no. 4, pp. 953-961, 2005.

[32] S. Agostini, J. G. Ryan, S. Tonarini, and F. Innocenti, “Drying and dying of a subducted slab: Coupled $\mathrm{Li}$ and $\mathrm{B}$ isotope variations in Western Anatolia Cenozoic Volcanism," Earth and Planetary Science Letters, vol. 272, no. 1-2, pp. 139-147, 2008.

[33] C. Martin, K. E. Flores, and G. E. Harlow, "Boron isotopic discrimination for subduction-related serpentinites," Geology, vol. 44, no. 11, pp. 899-902, 2016.

[34] S. Arnórsson and A. Andrésdóttir, "Processes controlling the distribution of boron and chlorine in natural waters in Iceland," 
Geochimica et Cosmochimica Acta, vol. 59, no. 20, pp. 4125-4146, 1995.

[35] R. B. Trumbull and M. Chaussidon, "Chemical and boron isotopic composition of magmatic and hydrothermal tourmalines from the Sinceni granite-pegmatite system in Swaziland," Chemical Geology, vol. 153, no. 1-4, pp. 125-137, 1999.

[36] A. Vengosh, A. Starinsky, Y. Kolodny, and A. R. Chivas, "Boron isotope geochemistry of thermal springs from the northern Rift Valley, Israel," Journal of Hydrology, vol. 162, no. 1-2, pp. 155-169, 1994.

[37] D. Widory, E. Petelet-Giraud, P. Négrel, and B. Ladouche, "Tracking the sources of nitrate in groundwater using coupled nitrogen and boron isotopes: A synthesis," Environmental Science \& Technology, vol. 39, no. 2, pp. 539-548, 2005.

[38] M. Pennisi, G. Bianchini, A. Muti, W. Kloppmann, and R. Gonfiantini, "Behaviour of boron and strontium isotopes in groundwater-aquifer interactions in the Cornia Plain (Tuscany, Italy)," Applied Geochemistry, vol. 21, no. 7, pp. 1169-1183, 2006.

[39] L. W. Deborah, L. Berry, W. Nathaniel et al., "Boron isotopic geochemistry of the McMurdo Dry Valley lakes, Antarctica," Chemical Geology, vol. 386, pp. 152-164, 2014.

[40] W. Palmucci and S. Rusi, "Boron-rich groundwater in Central Eastern Italy: a hydrogeochemical and statistical approach to define origin and distribution," Environmental Earth Sciences, vol. 72, no. 12, pp. 5139-5157, 2014.

[41] M. Masaaki, O. Takao, and K. Rob, "Chlorine isotopic compositions of deep saline fluids in Ibusuki coastal geothermal region, Japan: using B-Cl isotopes to interpret fluid sources," Isotopes in Environmental and Health Studies, vol. 51, no. 2, pp. 285-299, 2015.

[42] Y. Kyoko, M. Seiya, I. Tsuyoshi, and K. Hodaka, "Boron isotope systematics of a fossil hydrothermal system from the Troodos ophiolite, Cyprus: water-rock interactions in the oceanic crust and subseafloor ore deposits," Chemical Geology, vol. 396, pp. 61-73, 2015.

[43] H. P. Qi, Y. H. Wang, Y. K. Xiao, D. P. Sun, L. Jin, and Y. Tang, "The preliminary study on the boron isotope of Chinese salt lakes," Chinese Science Bulletin, vol. 38, no. 7, p. 634, 1993 (Chinese).

[44] Y. K. Xiao, D. P. Sun, Y. H. Wang, H. P. Qi, and L. Jin, "Boron isotopic compositions of brine, sediments and source water in Da Qaidam Lake, Qinghai, China," Geochimica et Cosmochimica Acta, vol. 56, pp. 1561-1568, 1992.

[45] Y. K. Xiao, P. V. Shirodlar, W. G. Liu, Y. H. Wang, and L. Jin, "Boron isotope geochemical study in qinghai salt lake, Qaidam basin," Progress in Natural Science, vol. 9, no. 7, pp. 612-618, 1999 (Chinese).

[46] Y. K. Xiao, H. Z. Wei, and D. Z. Yin, "Progress on isotopic geochemistry of boron and chlorine in salt lakes," Journal of Salt Lake Research, vol. 8, no. 1, pp. 30-40, 2000 (Chinese).

[47] A. Vengosh, A. R. Chivas, A. Starinsky, Y. Kolodny, Z. Baozhen, and Z. Pengxi, "Chemical and boron isotope compositions of non-marine brines from the Qaidam Basin, Qinghai, China," Chemical Geology, vol. 120, no. 1-2, pp. 135-154, 1995.

[48] W. G. Liu, Y. K. Xiao, Z. C. Peng, Z. S. An, and X. X. He, "Boron concentration and isotopic composition of halite from experiments and salt lakes in the Qaidam Basin," Geochimica et Cosmochimica Acta, vol. 64, no. 13, pp. 2177-2183, 2000.

[49] W. M. Deng, H. J. Sun, and Y. Q. Zhang, "Petrogenesis of Cenozoic potassic volcanic rocks in the Nangqen basin," Acta Geologica Sinica (English Edition), vol. 75, no. 1, pp. 27-40, 2001.
[50] Z. Qi, Y. Li, C. Wang, T. Sun, and J. Zhang, "Organic geochemistry of the Paleocene-Eocene oil shales of the Gongjue formation, Nangqian basin, east-central Tibetan plateau," Oil Shale, vol. 34, no. 1, pp. 1-14, 2017.

[51] D. Yang and P. Wang, "The determinations of plateau age by ${ }^{40} \mathrm{Ar} /{ }^{39} \mathrm{Ar}$ dating on Cenozoic calc-alkalic trachytes of Nangqen Basin, northern transverse mountains," in Contribution to the Geology of the Qinghai-Xizang (Tibet) Plateau, vol. 19, pp. 3944, 1988 (Chinese).

[52] Y.-H. Jiang, S.-Y. Jiang, H.-F. Ling, and B.-Z. Dai, "Lowdegree melting of a metasomatized lithospheric mantle for the origin of Cenozoic Yulong monzogranite-porphyry, east Tibet: geochemical and $\mathrm{Sr}-\mathrm{Nd}-\mathrm{Pb}-\mathrm{Hf}$ isotopic constraints," Earth and Planetary Science Letters, vol. 241, no. 3-4, pp. 617-633, 2006.

[53] W. M. Deng, H. J. Sun, and Y. Q. Zhang, "Petrogenesis of Cenozoic potassic volcanic rocks in Nangqen Basin," Chinese Journal of Geology, vol. 36, no. 3, pp. 304-318, 2001 (Chinese).

[54] H. J. Sun, W. M. Deng, and Y. Q. Zhang, "Petrology of the Cenozoic high-K alkaline volcanic rocks in angqen Basin," Geology Review, vol. 145, pp. 958-965, 1999 (Chinese).

[55] Y. Q. Ma, Y. K. Xiao, M. Y. He, J. Xiao, Q. Shen, and S. X. Jiang, "Boron isotopic composition of Paleozoic brachiopod and coeval coral calcites in Yunnan-Guizhou Plateau, China," Science China Earth Sciences (English Edition), vol. 54, no. 12, pp. 1912-1925, 2011.

[56] H. Z. Yuan, L. P. Zhang, M. M. Geng, and L. W. Xu, "Comparison of methods for hydrogen and oxygen isotopes analysis of water samples by flish HT and gas bench II-IRMS system," Journal of Chinese Mass Spectrometry Society, vol. 34, no. 6, pp. 347-352, 2013 (Chinese).

[57] A. E. Gue, B. Mayer, and S. E. Grasby, "Origin and geochemistry of saline spring waters in the Athabasca oil sands region, Alberta, Canada," Applied Geochemistry, vol. 61, pp. 132-145, 2015.

[58] A. Vengosh, A. R. Chivas, M. T. McCulloch, A. Starinsky, and Y. Kolodny, "Boron isotope geochemistry of Australian salt lakes," Geochimica et Cosmochimica Acta, vol. 55, no. 9, pp. 2591-2606, 1991.

[59] X. S. Niu, X. F. Liu, and W. X. Chen, "Hydrochemical characteristic and oringin for salt springs water in dogai coring area of north Qiangtang Basin, Tibet," Acta Gelogica Sinica, vol. 88, no. 6, pp. 315-318, 2014.

[60] J. C. Fontes, M. Yousfi, and G. B. Allison, "Estimation of longterm, diffuse groundwater discharge in the northern Sahara using stable isotope profiles in soil water," Journal of Hydrology, vol. 86, no. 3-4, pp. 315-327, 1986.

[61] F. J. Alcalá and E. Custodio, "Using the $\mathrm{Cl} / \mathrm{Br}$ ratio as a tracer to identify the origin of salinity in aquifers in Spain and Portugal," Journal of Hydrology, vol. 359, no. 1-2, pp. 189-207, 2008.

[62] G. Rittenhouse, "Bromide in oil field waters and its use in determining possibilities of origin of these waters," American Association Petroleum Geology Bulletin, vol. 51, no. 12, pp. 24302440, 1967.

[63] J. T. Freeman, "The use of bromide and chloride mass ratios to differentiate salt-dissolution and formation brines in shallow groundwaters of the Western Canadian Sedimentary Basin," Hydrogeology Journal, vol. 15, no. 7, pp. 1377-1385, 2007.

[64] J. Fabryka-Martin, D. O. Whittemore, S. N. Davis, P. W. Kubik, and P. Sharma, "Geochemistry of halogens in the Milk River aquifer, Alberta, Canada," Applied Geochemistry, vol. 6, no. 4, pp. 447-464, 1991. 
[65] S. N. Davis, D. O. Whittemore, and J. Fabryka-Martin, "Uses of chloride/bromide ratios in studies of potable water," Groundwater, vol. 36, no. 2, pp. 338-350, 1998.

[66] A. Vengosh and M. J. Hendry, "Chloride-bromide- $\delta 11 \mathrm{~B}$ systematics of a thick clay-rich aquitard system," Water Resources Research, vol. 37, no. 5, pp. 1437-1444, 2001.

[67] I. Cartwright, T. R. Weaver, and L. K. Fifield, " $\mathrm{Cl} / \mathrm{Br}$ ratios and environmental isotopes as indicators of recharge variability and groundwater flow: An example from the southeast Murray Basin, Australia," Chemical Geology, vol. 231, no. 1-2, pp. 38-56, 2006.

[68] C. J. Eastoe, A. Long, and L. P. Knauth, "Stable chlorine isotopes in the Palo Duro Basin, Texas: evidence for preservation of Permian evaporite brines-I. Theory," Geochimica et Cosmochimica Acta, vol. 63, no. 9, pp. 1375-1382, 1999.

[69] Y. Kolodny, A. Katz, A. Starinsky, T. Moise, and E. Simon, "Chemical tracing of salinity sources in Lake Kinneret (Sea of Galilee), Israel," Limnology and Oceanography, vol. 44, no. 4, pp. 1035-1044, 1999.

[70] S. V. Panno, K. C. Hackley, H. H. Hwang et al., "Characterization and identification of $\mathrm{Na}-\mathrm{Cl}$ sources in ground water," Groundwater, vol. 44, no. 2, pp. 176-187, 2006.

[71] Y. Bo, C.-L. Liu, P.-C. Jiao, Y.-Z. Chen, and Y.-T. Cao, "Saline spring hydrochemical characteristics and indicators for potassium exploration in southwestern and northern Tarim Basin, Xinjiang," Acta Geoscientia Sinica, vol. 34, no. 5, pp. 594-602, 2013 (Chinese).

[72] H. B. Tan, W. D. Ma, X. Y. Zhang, and C. D. Cao, "Hydrochemical characteristics of brines and application to locating potassium in western Tarim Basin," Geochimica et Cosmochimica Acta, vol. 33, no. 2, pp. 152-158, 2004 (Chinese).

[73] A. Sanyal, N. G. Hemming, W. S. Broecker, D. W. Lea, H. J. Spero, and G. N. Hanson, "Oceanic pH control on the boron isotopic composition of foraminifera: Evidence from culture experiments," Paleoceanography, vol. 11, no. 5, pp. 513-517, 1996.

[74] A. Sanyal, J. Bijma, H. Spero, and D. W. Lea, "Empirical relationship between $\mathrm{pH}$ and the boron isotopic composition of Globigerinoides sacculifer: Implications for the boron isotope paleo-pH proxy," Paleoceanography, vol. 16, no. 5, pp. 515-519, 2001.

[75] M. R. Palmer, A. J. Spivack, and J. M. Edmond, “Temperature and $\mathrm{pH}$ controls over isotopic fractionation during adsorption of boron on marine clay," Geochimica et Cosmochimica Acta, vol. 51, no. 9, pp. 2319-2323, 1987.

[76] E. F. Rose, M. Chaussidon, and C. France-Lanord, "Fractionation of boron isotopes during erosion processes: The example of Himalayan rivers," Geochimica et Cosmochimica Acta, vol. 64, no. 3, pp. 397-408, 2000.

[77] G. Gou, Q. Wang, D. A. Wyman, X. Xia, G. Wei, and H. Guo, "In situ boron isotopic analyses of tourmalines from Neogene magmatic rocks in the northern and southern margins of Tibet: Evidence for melting of continental crust and sediment recycling," Solid Earth Sciences, vol. 2, no. 2, pp. 43-54, 2017.

[78] H. P. Schwarcz, E. K. Agyei, and C. C. McMullen, "Boron isotopic fractionation during clay adsorption from sea-water," Earth and Planetary Science Letters, vol. 6, no. 1, pp. 1-5, 1969.

[79] A. Yin and T. M. Harrison, "Geologic evolution of the himalayan-tibetan orogen," Annual Review of Earth \& Planetary Sciences, vol. 28, no. 28, pp. 211-280, 2003.

[80] P. Molnar and J. M. Stock, “Slowing of India’s convergence with Eurasia since $20 \mathrm{Ma}$ and its implications for Tibetan mantle dynamics," Tectonics, vol. 28, no. 3, pp. 1-11, 2009.
[81] A. A. Gurenko and M. Chaussidon, "Boron concentrations and isotopic composition of the icelandic mantle: Evidence from glass inclusions in olivine," Chemical Geology, vol. 135, no. 1-2, pp. 21-34, 1997.

[82] H. Palme and H. O’Neill, "Cosmochemical estimates of mantle composition," Treatise on Geochemistry, no. 2, pp. 1-38, 2007.

[83] S. Zhang, M. J. Henehan, P. M. Hull et al., "Investigating controls on boron isotope ratios in shallow marine carbonates," Earth and Planetary Science Letters, vol. 458, pp. 380-393, 2017.

[84] M. P. Zheng, J. Xiang, X. J. Wei et al., The Salt Lakes of QinghaiTibet Plateau, Beijing Science and Technology Press, Beijing, China, 1989 (Chinese).

[85] M. Chaussidon and F. Albarède, "Secular boron isotope variations in the continental crust: an ion microprobe study," Earth and Planetary Science Letters, vol. 108, no. 4, pp. 229-241, 1992. 

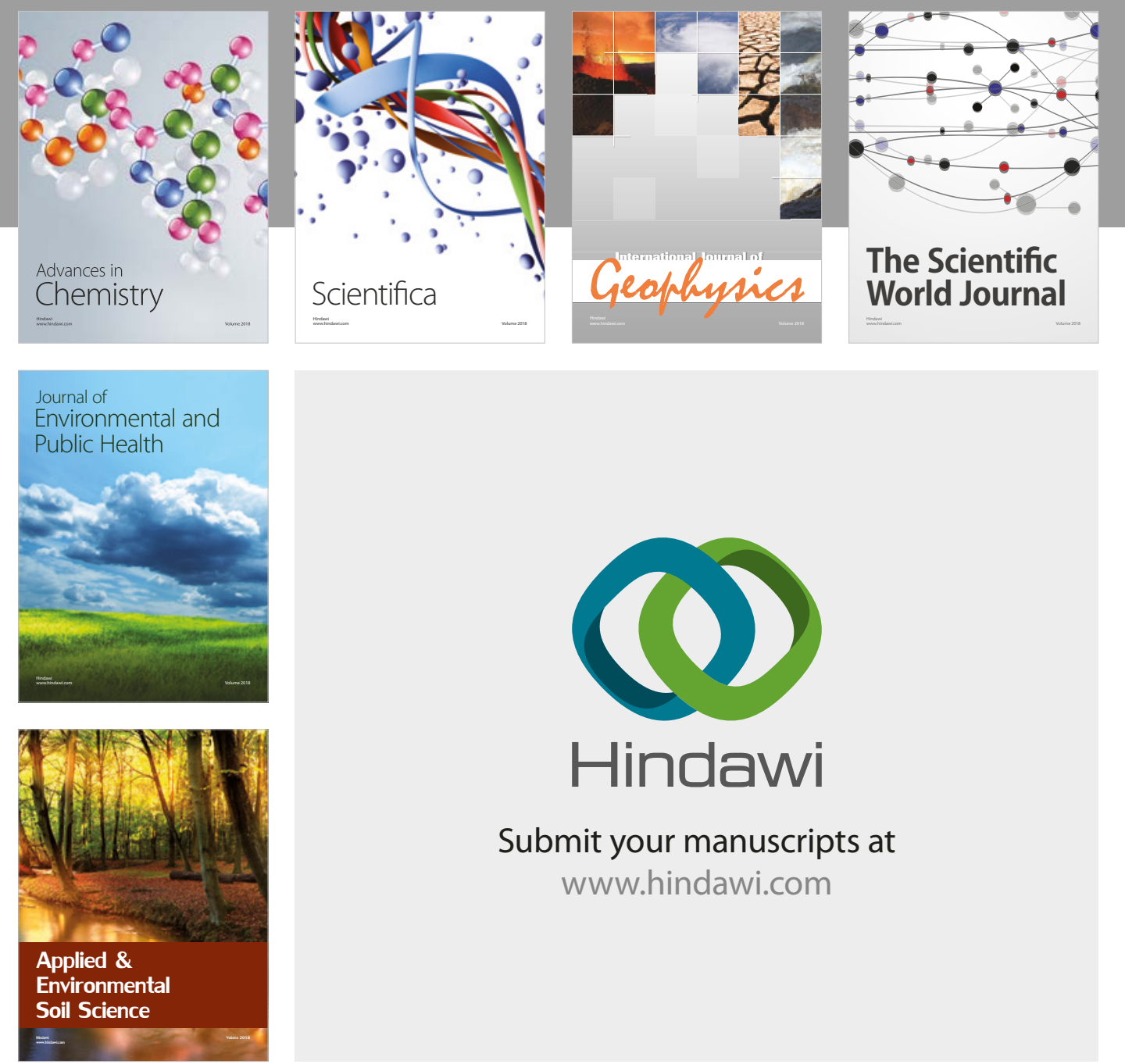

The Scientific

\section{World Journal}
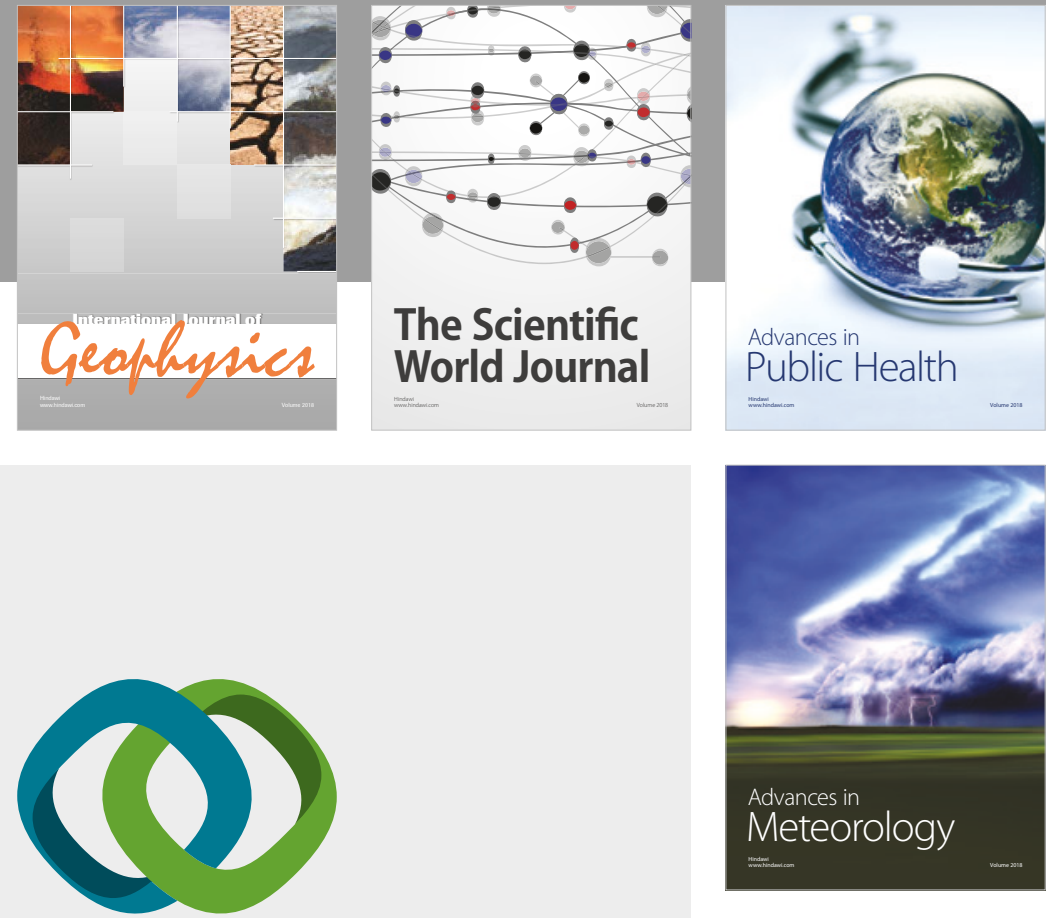

Advan

Public Health

\section{Hindawi}

Submit your manuscripts at

www.hindawi.com
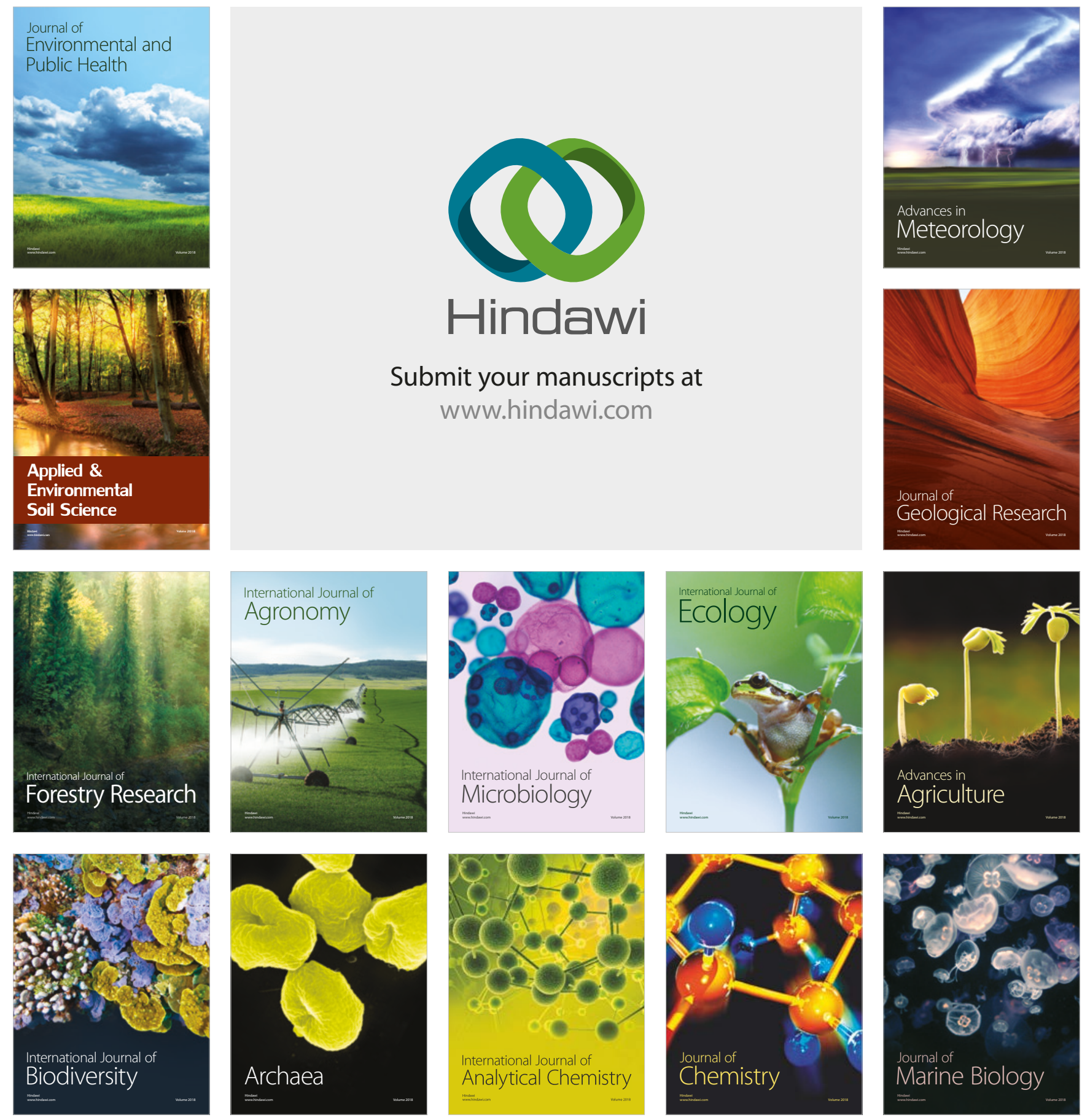